\title{
ТВОРЧА ДІЯЛЬНІСТЬ ВОЛОДИМИРА СУХОВЕРСЬКОГО В КОНТЕКСТІ РОЗВИТКУ МУЗИЧНОї ОСВІТИ УКРАЇНИ НОВІТНЬОї ДОБИ
}

\begin{abstract}
Мета роботи. Висвітлення характерних особливостей творчої діяльності Володимира Суховерського, які вплинули на якісне становлення музичної освіти України за новітньої доби. Методологія дослідження базується на комплексному підході до оцінки особистості в розвитку музичного мистецтва держави. Наукова новизна полягає у розкритті своєрідності впливу особистості на процес розвитку музичної освіти та виконавства в обумовлений період. Висновки. Аналіз творчої діяльності Володимира Суховерського дозволив виявити характерні риси музичної освіти, визначити особливості функціонування навчального комплексу « коледж - академія» як чинник реального втілення інноваційного підходу до здійснення навчального процесу і визначає перспективи його розвитку.

Ключові слова: особистість, регіон, держава, навчальний комплекс, музичне виконавство, творча діяльність, фрахова освіта.

Васюта Олег Павлович, кандидат искусствоведения, доцент, профрессор кафедры художественных дисциплин Национального университета "Черниговский коллегиум им. Т.Г.Шевченко

Творческая деятельность Владимира Суховерского в контексте развития музыкальной культуры Украины нового времени

Цель работы. Освещение характерных особенностей творческой деятельности Владимира Суховерского, которая оказала влияние на качественное становление музыкальной культуры Украины нового времени. Методология исследования базируется на комплексном подходе к оценке роли личности в развитии музыкального искусства региона. Научная новизна состоит в раскрытии своеобразия воздействия творческой личности на процесс становления музыкального образования в определённый период времени. Выводы. Анализ творческой деятельности Владимира Суховерского позволил определить характерные черты музыкального образования нового времени, обозначить особенности функционирования учебного комплекса «колледж-академия» как реальное воплощение инновационного подхода к осуществлению учебного процесса, что определяет перспективы его развития.
\end{abstract}

Ключевые слова: личность, особенность, регион, учебный комплекс, музыкальное исполнительство, творческая деятельность, специальное образование.

Vasuta Oleg, Ph.D. in Art History, Associate Professor, Professor of Chairs of art disciplines of the National University "T.G. Shevchenko Chernihiv College"

Creative activity of Vladimir Sukhoversky in the context of development of musical culture of Ukraine

The purpose of the article is to highlight the characteristic features of creative activities of Vladimir Sukhoversky, which influenced the qualitative formation of the musical culture of the Chernihiv region of modern times. The research methodology is based on an integrated approach to the assessment of the role of personality in the development of musical art in the area. The scientific novelty consists of revealing the originality of the impact of a creative person on the process of the formation of music education in a certain period. Conclusions. Analysis of the creative activity of Vladimir Sukhoversky allowed determining the characteristics of the musical education of modern times, educational complex "college - academy" as a real embodiment innovative approach to the implementation of the educational process that determines the prospects for its development. Intercultural interaction within the complex is a unique example of synergistic action as self-organization of an open educational system, which is in constant dialogue with the cultural environment and has a multiplicity of self-development scenarios. V. Sukhoversky 's activity found its expression in the music - pedagogical practice of the state, musical performance and musicology and influenced: formation of the modern structure of music professional education, which was realized in the activity of the educational complex of innovative direction; improving the creative potential of student youth by engaging in various forms of musical performance and scientific and search activities; definition of meaningful lines of further development of music culture of Ukraine of the modern era. education.

Key words: personality, feature, region, educational complex, musical performance, creative activity, special

Актуальність теми дослідження. 31993 року Суховерський Володимир Михайлович - директор вищого навчального закладу «Чернігівський музичний коледж ім. Л.М. Ревуцького» Чернігівської обласної ради. Очолює Чернігівське обласне відділення Національної всеукраїнської музичної спілки ( 1995). Має почесне звання «Заслужений діяч мистецтв України»(1998). Враховуючи високі досягнення в підготовці мистецьких кадрів, наказом Міністерства культури і мистецтв України створений навчальний комплекс «Національна музична академія України імені П.І. Чайковського - Чернігівське музичне училище імені Л.М. Ревуцького»(1998). За ініціативи В. Суховерського започаткований міжнародний 
фестиваль - конкурс молодих композиторів імені Л.М. Ревуцького (2004) за участі молодих музикантів з Німеччини, Англії, Польщі, Японії, який підносить міжнародний авторитет навчального комплексу, сприяє поширенню творчості Л.М. Ревуцького в європейському культурному просторі. У рамках фестивалю симфонічний оркестр неодноразово виїжджав до Німеччини, а духовий оркестр - до Польщі. За підсумками «Року культури» в Україні (2004) Міністерство культури і мистецтв України визнало В. Суховерського кращим керівником мистецького навчального закладу України серед вищих навчальних закладів I-II рівня акредитації з врученням йому диплома та Золотої медалі, Подяки Кабінету Міністрів України. Нагороджений орденом « За заслуги» III ступеня (2004). У 2009 році нагороджений Почесною відзнакою «Орден за видатні досягнення у музичному мистецтві» Національної музичної академії України імені П.І. Чайковського. Творча діяльність Суховерського В.М. позначена високою виконавською культурою. (Він є Лауреатом Міжнародного конкурсу виконавців на народних інструментах ім. І. Паницького у 1983). Постійно виступає з концертами в Україні, Росії, Грузії, Польщі, Болгарії, Німеччині, Голландії. Автор статей та брошур про музичну культуру України. Ініціював відкриття на базі навчального комплексу Музею історії музичної культури та мистецтва Чернігівщини, Кімнату-музей Г.Г.Верьовки та Л.М.Ревуцького. Указом Президента України нагороджений орденом «За заслуги» II ступеня (2010). На з'їзді Національної Всеукраїнської музичної спілки обраний в якості секретаря. У 2015 році нагороджений медаллю «За жертовність і любов до України» УПЦ КП. 32016 року член комісії по реформуванню мистецької освіти Міністерства культури України. Неодноразово брав участь у засіданні Комітету освіти і науки Верховної ради України. 32017 року член комісії мистецької освіти Національної академії мистецтв України.

У загальній системі музично - професійної діяльності країни спостерігається певне акцентування музично - освітніх рухів на рівні регіону ( локусу), які сприяють формуванню якісно нового інтелектуального і творчого арсеналу у відповідності до вимог сталого суспільства з урахуванням особистостей конкретного мистецького середовища на основі за діяння фундаментальних засад мистецтва українського народу, який на конституційному рівні закріпив незворотність руху до спільного Європейського Дому [1]. В цьому контексті проблематика ролі особистості у сфері розвитку музичної культури регіону, тлумачення цього явища науковцями і практичними діячами музичного мистецтва ще не достатньо досліджена та імплементована у креативний навчально - освітній простір. Очевидно, що обумовлена проблема стає ще й певним орієнтиром, коли виникає необхідність на різних рівнях суспільної свідомості обґрунтувати фахове ставлення до музично-освітнього процесу, як прояву творчої свободи демократичного суспільства при виборі музичних професій молоді, а головне, у здатності мистецького закладу створити умови для реалізації духовного потенціалу молоді її творчої самореалізації на основі дійсних художньо - естетичних ідеалів, а також тоді, коли виникають певні ризики ( фрінансові, законодавчі) щодо втрати історичних напрацювань вітчизняної музичної освіти. Адже неспроможність суспільства щодо усунення ризиків розвитку вкрай негативно позначитися на вихованні молоді та її здатності вірно орієнтуватися в музичних тенденціях часу, втілювати і розрізняти підходи до музично-виховного процесу, особливо в сфері академічного мистецтва. Молодь необхідно спрямовувати до осмислення глибинних мистецьких процесів та прогнозування наслідків від реалізації власної творчої діяльності. Роль мистецької особистості у формуванні якісних змін в сучасному суспільстві $є$ тим помітнішою і значимою, чим більше вона відповідає на духовні запити часу. В цьому сенсі творча діяльність В. Суховерського здійснює суттєвий плив на процес трансформаційних змін музичного простору держави. Його адаптивність, пластичність, здатність не лише оперативно реалізувати музично - фахові компетентності у навчальний процес, а й наполегливий розвиток як особистого потенціалу, так і здатності щодо реалізації навчально- педагогічних інтересів, сформували імідж навчального комплексу із сучасними баченнями творчої самореалізації молоді, спрямованих на здійснення різнобічної професійної мистецької діяльності. Подібна фахова реактивність і цілеспрямованість у діях дає змогу Володимиру Суховерському почувати себе впевнено і вільно в широкому інформаційному просторі рідного Чернігова, області, держави, що є ознакою мистецької особистості сьогодення. Аналізуючи результати творчої діяльності Володимира Суховерського ми вирішуємо проблему пошуку ефективних дій у сорері музичного мистецтва; методів практичного запровадження інноваційних спрямувань освітнього процесу, особливо у його середній ланці ( від школи до ЗВО). Сьогодні відбувається становлення стійких світоглядних позицій на рівні суспільної свідомості, здатної відстояти те, що дасть справжню силу і розвиток нашій духовності в майбутньому. Мистецька особистість по - своєму виявляє свої інтереси, віддаючи перевагу певним напрямам творчої діяльності, реалізуючи власний творчий потенціал. Тобто «мистецьке его» реалізується як процес накопичення творчого досвіду, духовної здатності до гнучкості, пластичності та динаміки своєчасних дій, які відображають її природу і фрахову сутність.

Мета статті. Висвітлення тенденцій творчої діяльності В. Суховерського, які відіграють консолідуючу роль у процесі формування якісних ознак новочасового музичного мистецтва України.

Аналіз останніх досліджень і публікацій. Окрім газетно - журнальних повідомлень, особистість В. Суховерського не розглядалася в контексті наукових досліджень.

Виклад основних положень. У сучасних регіональних музикознавчих дослідженнях, присвячених проблемі музичної культури, пріоритетним завданням є визначення впливу навчального комплек- 
су «Національна музична академія України імені П.І. Чайковського - Чернігівське музичне училище ( коледж) імені Л.М. Ревуцького» на фрормування і подальший розвиток стратегічних напрямків музичної культури, фахової музичної освіти, музичного виконавства, музикознавства та широкого спектра педагогіки мистецтв.[2] Тобто обшару музичної дійсності, який сучасна освітня практика (і не лише регіонального рівня) повинна належним чином задіяти на рівні практичної реалізації в межах держави. Отже роль навчального комплексу у процесі трансформаційних змін її змісту є очевидною і потребує відповідного музикознавчого осмислення. 3 цієї точки зору вихідним і принциповим питанням організаційно - творчої діяльності В. Суховерського є діалектичне бачення історичного розвитку коледжу (1904-2019) як єдність традиційного та інноваційного. За 115 років свого існування заклад неодноразово змінював свій статус, зберігаючи послідовність, наступність кращих музично - педагогічних практик фрахового виховання творчої молоді. На всіх етапах діяльності педагогічний склад яскраво виявляв свій художньо - естетичний потенціал, інтегруючи різні види музично - педагогічної діяльності: пізнавальну (навчальну), музично- виконавську, науково - методичну. ( Коледж $є$ головною ланкою організації навчально - методичної діяльності мистецьких навчальних закладів Чернігівської області різного рівня підпорядкування та акредитації).

Академічне музичне мистецтво у його історичній ретроспективі $є$ дієвим засобом насичення зазначених напрямків діяльності. Яскравим прикладом врахування класичних та інноваційних підходів $€$ напрацьовання структури закладу в якому окремими ланками навчального процесу функціонують різні відділи: диригентсько-хоровий, спеціального фортепіано, струнно-смичкових, народних, духових та ударних інструментів, теорії музики, сольного співу, музичного мистецтва естради, загальноосвітніх дисциплін. Кожен відділ представлений учнівськими творчими колективами: мішаний хор ( керівник народна артистка України М. Гончаренко), симфонічний оркестр ( керівник заслужений артист України О.Шевчук), оркестр народних інструментів ( керівник В.Фалалєєв), духовий оркестр ( керівник І.Кішман), ансамбль бандуристів «Зачарована Десна» ( керівник заслужена артистка України Р.Борщ), камерний оркестр ( керівник Н.Полонська), естрадний оркестр ( керівник М.Гірня), ансамбль народних інструментів «Гармоніка» (керівник заслужений артист України В.Кожан). У широкому спектрі творчої діяльності комплексу активно використовуються різні фрорми камерно - інструментального виконавства: дуети, терцети, квартети, квінтети, секстети.

Діяльність учнівських колективів $є$ реалізацією мистецьких поглядів В. Суховерського щодо дієвості та інтегративності музичного виконавства, яке консолідує різні ланки навчального процесу і закладає основи дієвої музичної професіоналізації особистості. Приміром, провідні мистецькі колективи Чернігівського обласного фрілармонійного центру фестивалів і концертних програм зі статусом «академічний» ( симфонічний оркестр «Філармонія», камерний хор ім. Д. Бортнянського, ансамбль пісні і танцю «Сіверські клейноди», народний хор і інші), сформовані з випускників коледжу. Не випадково, диригентство є професійним пріоритетом В.Суховерського. Відданість музично-виконавській культурі допомагає йому у стверджені колективного музичення як складової навчального процесу, привертанні уваги студентського середовища до сучасних тематичних напрямів, стилів і жанрів музики. Спрямування їх в руслі накопичення основ раціонального музичного мислення, фрормування технічних навичок музичення з максимальним наближенням до реальних умов майбутньої професійної діяльності. Сприянням у формуванні індивідуальних проявів емоційно - чуттєвої сфери молодих виконавців. За ініціативи В. Суховерського кожен навчальний рік завершується гранд-концертом на сцені Чернігівського обласного академічного театру ім.. Т.Г. Шевченка і трактується як важливий елемент музично педагогічної технології спрямованої на: 1) розвиток емоційно- чуттєвого сприйняття молоддю широкого світу музичного мистецтва; 2) створення умов для творчого самовираження особистості за рахунок участі у хорах, оркестрах, ансамблях тощо; 3) надбання емоційно - технічних, організаційно - творчих навичок колективного музичення, що фрормують самодисципліну і здатність до синергатичних дій особистості у культурному просторі.

Суттєве нарощення широкого загалу музично - виховного процесу сприяло утвердженню навчального комплексу «Національна музична академія України ім. П.І. Чайковського - Чернігівський музичний коледж ім. Л.М. Ревуцького», що дозволило на новому якісному рівні приступити до розв'язання наступних проблем музично-педагогічної практики шляхом:

1) внесення коректив до спільних навчальних планів у відповідності до угоди про співпрацю у здійсненні музично-виховного процесу; 2) визначення у якості спільного пріоритету щодо максимальної підтримки творчого потенціалу особистості та формуванням внутрішньої потреби постійного перебування студентів у стані творчого пошуку; 3) виокремлення музично - виконавської, науково - дослідницької, педагогічної роботи як засобу формування спеціальних компетенцій молоді, спрямованих на самовдосконалення, самореалізацію через творчу мотивацію відтворення духовних смислів особистості як джерела саморуху від «малого до великого» з метою входження у світ «відкритих проблем» висококонкуретного мистецького середовища; 4) створення реальних умов для майбутньої професійної діяльності через участь у спільних мистецьких проектах, наукових студентських конференціях; щорічному проведенні на базі коледжу конкурсу молодих композиторів ім.. Л.М. Ревуцького з формуванням на цій основі інтегративних духовних цінностей особистості; 5) напрацювання спільних змістовних ліній з урахуванням світових мистецьких інновацій; 6) коригування «звичних» підходів, які гальмують 